\title{
ANALISIS KESALAHAN BERBAHASA PADA MAJALAH TOGA EDISI III BULAN DESEMBER TAHUN 2018
}

\author{
Kusuma Sari ${ }^{1}$, Rizki Joko Nurcahyo ${ }^{1}$, Kartini ${ }^{1}$ \\ ${ }^{1}$ Institut Agama Islam Negeri Surakarta \\ Email: kusumasari598@gmail.com
}

\begin{abstract}
Abstrak
Majalah Toga merupakan majalah karya mahasiswa bidik misi IAIN Surakarta. Majalah ini ditulis menggunakan bahasa Indonesia sehingga dalam penulisan majalah harus sesuai dengan kaidah kebahasaan yang berlaku di era saat ini. Tetapi dalam majalah Toga masih ditemukan beberapa kesalahan dalam penggunaan kaidah maupun kebahasaan yang tidak sesuai dengan kaidah yang berlaku di era saat ini. Tujuan penelitian ini adalah untuk mendiskripsikan bentuk-bentuk kesalahan berbahasa dalam penulisan majalah Toga. Teknik penelitian yang digunakan dalam penelitian ini adalah teknik tulis. Analisis yang dipakai dalam penelitian ini adalah analisis interaktif. Langkahlangkah dalam analisis interaktif meliputi 1) pengumpulan data, 2) pegidentifikasian kesalahan, 3) penjelasan kesalahan, 4) pengklasifikasian kesalahan, pengevaluasian kesalahan. Hasil dari penelitian ini adalah ditemukan berbagai kesalahan berbahasa dalam tataran ejaan dan tataran linguistik seperti fonologi, morfologi, sintaksis, dan semantik. Secara garis besar hasil dari penelitian ini lebih dominan kesalahan dalam tataran ejaan.
\end{abstract}

Kata kunci: kesalahan berbahasa, linguistik

\begin{abstract}
Toga Magazine is a magazine by the Surakarta IAIN bidik misi student. This magazine is written using Indonesian so that in writing a magazine it must be in accordance with the rules of language that apply in the current era. But in Toga magazine there are still some errors in the use of rules and linguistics that are not in accordance with the rules that apply in the current era. The purpose of this study is to describe the forms of language errors in writing Toga magazine. The technique used in this study is written technique. The analysis used in this study is interactif analysis. The steps in interactif analysis include 1) data collection, 2) identification of errors, 3) explanation of errors, 4) classification of errors, evaluation of errors. The results of this study are found in various language errors in spelling and linguistic levels such as phonology, morphology, syntax, and semantics. Broadly speaking, the results of this study predominate in spelling errors. .
\end{abstract}

Keywords: language errors, linguistics.

\section{PENDAHULUAN}

Setiap manusia selalu membutuhkan informasi dalam kehidupan bersosial dan bermasyarakat. Informasi-informasi yang dibutuhkan oleh manusia dapat diperoleh melalui sebuah media massa. Media massa adalah salah satu sarana komunikasi dan sumber informasi yang paling sering digunakan oleh manusia. Media massa memiliki berbagai fungsi yaitu untuk memberi informasi tentang suatu kejadian, untuk melaksanakan sebuah control sosisal dalam bermasyarakan, dan untuk sarana hiburan. Oleh karena itu, media massa harus dimanfaatkan secara maksimal dan bertanggung jawab sebagai salah satu sarana untuk memenuhi kebutuhan informasi manusia yang berkenaan 
dengan proses komunikasi massa, riset media, manajemen, pengelolaan industri, dan sebagainya.

Media massa memiliki berbagai bentuk dalam penyajian informasi-informasinya. Salah satu bentuk penyajian tersebut adalah media massa cetak. Media massa cetak merupakan sarana penyajian informasi dalam bentuk cetakan misalnya surat kabar, brosur informasi, majalah, dan lain-lain. Informasi dalam media massa cetak ditujukan untuk mempengaruhi atau mempersuasifkan secara rasional. Selain itu, informasi-informasi yang disampaikan dalam media massa cetak pun begitu lengkap menjawab rumusan $5 \mathrm{~W}+1 \mathrm{H}$ (what, who when, where, why, dan how).

Majalah sebagai salah satu bentuk media massa cetak dapat digunakan sebagai alternatif sumber tambahan materi pembelajaran bahasa Indonesia. Hal itu dapat terjadi apabila kaidah kebahasaan yang digunakan dalam majalah tersebut sudah memenuhi acuan yang digunakan dalam bahasa Indonesia sehingga penggunaan kaidah kebahasan sangat penting dalam penulisan sebuah majalah sebagai salah satu bentuk sarana penyampaian sebuah informasi dalam bentuk cetak.

Dalam penulisan majalah, pengunaan ejaan dan kaidah kebahasaan yang sesuai dengan acuan bahasa Indonesia sangatlah penting. Hal ini dikarenakan penulisan majalah sangat berpengaruh terhadap informasi yang akan disampaikan sehingga informasi tersebut dapat diterima dengan mudah atau tidak oleh pembaca. Oleh karena itu, penulisan majalah harus terhindar dari kesalahan penggunaan ejaan dan kaidah kebahasaan karena akan mempengaruhi informasi yang akan disampaikan, misalnya informasi menjadi ambigu dan informasi menjadi membingungkan sehingga pembaca mengalami kesulitan dalam menerima dan memahami informasi yang disampaikan dalam majalah tersebut.

Salah satu media massa cetak yang bermanfaat di kampus IAIN Surakarta adalah Majalah Toga. Majalah Toga merupakan majalah yang diterbitkan oleh organisasi mahasiswa Bidikmisi IAIN Surakarta. Majalah toga mengangkat tema tentang pimred, tematik atau disesuaikan dengan situasi dan kondisi kampus pada saat pembuatan majalah tersebut. Namun, secara garis besar Majalah Toga berisi tentang informasi-informasi perkembangan kampus dan karya-karya tulis mahasiswa IAIN Surakarta.

Secara garis besar penulisan Majalah Toga menggunakan bahasa Indonesia. Oleh karena itu, dalam proses penulisannya, Majalah Toga tidak terlepas dari kesalahan-kesalahan dalam penggunaan kaidah bahasa Indonesia. Kesalahan-kesalahan tersebut biasanya terjadi karena kondisi dan latar belakang pengguna bahasa tersebut. Hal tersebut sesuai dengan pendapat Setyawati (2010) yang mengemukakan bahwa kesalahan berbahasa dapat terjadi karena beberapa hal, misalnya pengaruh bahasa pertama, kekurangpahaman pengguna bahasa, dan pengajaran bahasa yang kurang maksimal.

Berdasarkan pernyataan tersebut, dipilihlah judul jurnal "Analisis Kesalahan Berbahasa pada Majalah Toga Edisi III Bulan Desember Tahun 2018"untuk mendeskripsikan bentuk-bentuk kesalahan berbahasa pada Majalah Toga. Hal tersebut dikarenakan masih terdapat berbagai kesalahan berbahasa dalam penulisan majalah yang menggunakan bahasa Indonesia. Hal ini sejalan dengan penelitian Monica Justiana (2018) yang berjudul“"'Kesalahan Berbahasa Pada Majalah Mimbar Edisi Juni Sampai Dengan Agustus 2016" dengan hasil terdapat beberapa kesalahan berbahasa pada majalah Mimbar edisi juni sampai agustus, yaitu (1) kesalahan ejaan meliputi penggunaan huruf kapital, tanda baca, kata turunan, dan unsur serapan, (2) kesalahan diksi, (3) kesalahan kalimat, dan (4) kesalahan paragraf.

\section{Pengertian Kesalahan Berbahasa}

Menurut Supriani dan Ida (2016: 70) Kesalahan berbahasa adalah pemakaian suatu bentuk tuturan dari berbagai unsur kebahasaan meliputi, kata, frasa, klausa, maupun kalimat yang menyimpang dari kaidah kebahasaan yang telah ditentukan. Adapun kaidah kebahasaan dalam bahasa Indonesia adalah Ejaan Bahasa Indonesia (EBI) yang disempurnakan dan Kamus Besar Bahasa Indonesia (KBBI) yang digunakan sebagai standar acuan dalam menentukan suatu bentuk tuturan yang benar atau salah. Senada dengan pendapat Supriani dan Ida, Johan dan Yusrawati (2017: 242) 
mengemukakan bahwa Kesalahan berbahasa secara sederhana dimaknai sebagai penggunaan bahasa, baik dilakukan secara lisan maupun tertulis yang menyimpang dari kaidah berbahasa. Berdasarkan kedua pendapat di atas dapat disimpulkan bahwa kesalahan berbahasa Indonesia merupakan penggunaan sebuah bahasa baik secara lisan maupun tulis yang meliputi kata, kalimat, atau paragraf yang menyimpang dari kaidah kebahasaan yang telah ditetapkan.

Inderasari (2017: 8) menjelaskan bahwa kesalahan berbahasa dapat dirinci lagi kedalam beberapa bidang, misalnya bidang lingusitik. Inderasari (2017: 8) menyebutkan bahwa berdasarkan bidang lingustik, kesalahan berbahasa dapat diklasifikasikan menjadi beberapa bidang kesalahan, meliputi bidang fonologi, morfologi, sintaksis, semantik, dan wacana. Senada dengan Inderasari, Supriani dan Ida (2017: 71) menyebutkan bahwa kesalahan dalam tataran linguistik mencakup beberapa unsur meliputi 1) kesalahan fonologis, 2) kesalahan morfologis, 3) kesalahan sisntaksis, dan 4) kesalahan leksikal atau pilihan kata. Berdasarkan kedua pendapat tersebut dapat diambil kesimpulan bahwa kesalahan dalam bidang linguistik terbagi menjadi beberapa bidang meliputi kesalahan fonologi, morfologi, sintaksis, semantik, dan kesalahan pemilihan diksi atau kata.

Berikut penjelasan dari masing-masing analisis kesalahan berbahasa pada bidang linguistik:

\section{Kesalahan Berbahasa pada Tataran Ejaan}

Kesalahan ejaan merupakan kesalahan dalam menuliskan kata dan penggunan tanda baca yang menyimpang dari ejaan yang telah ditetapkan yaitu Ejaan Bahasa Indonesia (EBI). Selanjutnya, Setyawati (2010) menjelaskan bahwa kesalahan pada bidang ejaan tidak hanya berfokus dalam cara mengeja suatu kata, tetapi lebih luas yaitu mengenai cara mengatur penulisan huruf menjadi unsur yang lebih besar seperti, frasa, klausa, maupun kalimat.

\section{Kesalahan Berbahasa pada Tataran Sintaksis}

Sintaksis merupakan cabang ilmu bahasa yang mempelajari perilah penggabungan atau penataan satuan-satuan lingual yang berupa kata untuk membentuk satuan yang lebih besar seperti frasa, klausa, dan kalimat (Wijana, 2011: 14). Senada dengan Wijana, Tarigan (dalam Slamet, 2014: 11) menjelaskan bahwa sintaksis adalah salah satu cabang dari tata bahasa yang membicarakan struktur kalimat, klausa, dan frasa.

\section{Kesalahan Berbahasa pada Tataran Semantik}

Veerhar (2001: 13) menjelaskan bahwa semantik adalah cabang ilmu bahasa yang mengkaji tentang arti atau makna. Senada dengan Veerhar, Suhardi (2013: 28) menjelaskan bahwa dalam semantik terdapat berbagai makna yang akan dikaji, makna tersebut meliputi makna leksikal, gramatikal, asosiatif, dan sebagainya. Selanjutnya, Chomsky (dalam Chaer, 2012: 285) menambahkan bahwa semantik tidak hanya mengkaji tentang makna kata, tetapi mengkaji makna pada sebuah kalimat.

Berdasarkan beberapa pendapat para ahli di atas dapat disimpulkan bahwa kesalahan berbahasa pada tataran semantik adalah kesalahan berbahasa yang berfokus pada penggunaan kata yang mengakibatkan perbedaan maupun penyimpangan makna dalam sebuah kalimat.

\section{Kesalahan Berbahasa pada Tataran Morfologi}

Morfologi merupakan cabang ilmu bahasa yang mengkaji seluk-beluk pembentukan suatu kata. Kata adalah bentuk bebas terkecil yang tidak dapat dibagi menjadi bentuk bebas yang lebih kecil lagi (Wijana, 2011: 55). Dalam kaitanya morfologi terdapat sebuah istilah proses morfologis yang berarti proses perubahan bentuk dasar suatu kata menjadi bentuk jadian. 
Dalam proses morfologis terdapat beberapa jenis diantaranya proses afiksasi, reduplikasi, dan pemajemukan. Wijana (2011: 63) menjelaskan bahwa afiksasi merupakan proses pembubuhan afiks kepada bentuk dasar. Dalam proses afiksasi terdapat beberapa istilah meliputi prefiks (awalan), sufiks (akhiran), dan infiks (sisipan). Kata yang mengalami proses afiksasi biasanya memiliki ciri-ciri tertentu seperti kata tersebut bersifat polimorfemik, memiliki makna gramatikal, dan mengalami perubahan kelas kata.

Reduplikasi merupakan proses perulangan bentuk dasar baik secara keseluruhan atau sebagian, baik dengan atau tanpa proses perubahan bunyi atau pembubuhan afiks (Wijana, 2011: 64). Reduplikasi dibagi menjadi beberapa jenis meliputi perulangan penuh, perulangan dengan perubahan bunyi, perulangan sebagian, dan perulangan disertai dengan afiksasi. Kata yang mengalami proses reduplikasi biasanya memiliki ciri-ciri tertentu seperti kata tersebut memiliki bentuk dasar, terdapat hubungan semantik kata ulang dengan kata dasar, dan terdapat kesaman kelas kata antara kata ulang dengan kata dasar.

Pemajemukan merupakan proses penggabungan bentuk dasar dengan bentuk dasar lain untuk membentuk sebuah kata yang baru (Wijana, 2011: 65). Dari beberapa uraian tersebut dapat diambil kesimpulan bahwa kesalahan berbahasa pada tataran morfologi meliputi kesalahan dalam penggunaan pembentukan kata melalui proses afiksasi, reduplikasi, dan pemajemukan.

\section{Kesalahan Berbahasa pada Tataran Fonologi}

Fonologi merupakan cabang ilmu bahasa yang mempelajari seluk beluk bunyi bahasa (Wijana, 2011: 14). Wijana menjelaskan bahwa fonologi memiliki dua bidang pengkajian yaitu fonetik dan fonemik. Fonetik merupakan salah satu cabang ilmu bunyi yang mempelajari sifat-sifat fisik sebuah bunyi bahasa. Sedangkan fonemik merupakan cabang ilmu bunyi yang mempelajari bunyi bahasa dalam kapasitasnya sebagai penanda pembeda makna.

Berdasarkan pernyataan tersebut dapat disimpulkan bahwa kesalahan pada tataran fonologi meliputi kesalahan dalam penggunaan bunyi bahasa. Misalnya kata kuping ditulis dengan kata kupimg hal tersebut merupakan kesalahan dalam kajian fonologi karena yang seharusnya fonem [n], tetapi ditulis dengan fonem [m] sehingga makna dari kata tersebut menjadi berbeda.

\section{METODE}

Metode penelitian yang digunakan dalam penelitian ini adalah metode penelitian kualitatif. Metode penelitian kualitatif yaitu penilitian yang bertujuan untuk mendiskripsikan secara sistematis, faktual, dan akurat mengenai fakta-fakta, sifat-sifat, serta hubungan fenomena yang satu dengan fenomena lain yang telah diselidiki (Inderasari, 2017: 11). Data dalam penelitian ini berasal dari kesalahan berbahasa Indonesia dalam majalah Toga edisi III bulan desember tahun 2018. Teknik pengumpulan data dalam penelitian ini adalah teknik catat. Selain itu, penelitian ini termasuk dalam jenis penelitian kualitatif sehingga data yang terkumpul dianalisis menggunakan analisis kualitatif yaitu data yang dianalisis berupa kata-kata bukan angka. Teknik yang digunakan dalam penelitian ini adalah teknik tulis. Analisis yang dipakai dalam penelitian ini adalah analisis interaktif. Langkahlangkah dalam analisis interaktif meliputi 1) pengumpulan data, 2) pegidentifikasian kesalahan, 3) penjelasan kesalahan, 4) pengklasifikasian kesalahan, pengevaluasian kesalahan.

\section{HASIL PENELITIAN DAN PEMBAHASAN}

\section{Hasil Penelitian}

Berdasarkan hasil observasi ditemukan beberapa kesalahan dalam tataran ejaan, sintasksis, semantik dan morfologi sehingga dapat ditarik kesimpulan pada Majalah Toga terdapat beberapa bentuk kesalahan-kesalahan yang tidak sesuai dengan kaidah kebahasaan yang berlaku di era saat ini. 
Pada kesalahan tataran ejaan ditemukan kesalahan pengunaan huruf kapital, kata depan dan cetak miring pada kalimat yang mengunakan bahasa daerah atau bahasa asing.

Pada kesalahan tataran sintaksis ditemukan kesalahan berbahasa pada frasa seperti pengunaan kata depan atau preposisi secara lagsung menandai berbagai hubungan makna antara konstituen di depan dan di belakang preposisi dan pembentukan kata superlatif atau berlebihan. Pada majalah bidikmisi terdapat beberapa pembetukan kata superlatif seperti a) bangga sekali b) sangat banyak sekali yang merupakan kalimat berlebihan.

Pada kesalahan tataran semantik ditemukan kesalahan peulisan kata yang tidak baku belum sesuai dengan kaidah kebahasaan. Dalam Majalah Toga ini juga terdapat kesalahan pemilihan kata (diksi) penggunaan kata-kata yang saling menggantikan dan dipaksakan dapat menimbulkan perubahan makna kalimat bahkan merusak struktur kalimat. Pada pilihan kata yang tidak tepat penggunaannya sehingga menimbulkan kesalahan.

Pada kesalahan tataran fonologi terdapat beberapa kesalahan pelafalan yang menyebabkan perubahan fonem, penambahan fonem, dan penghilangan fonem suatu kata. Dalam Majalah Toga ini ditemukan beberapa kata yang menghilangkan fonem suatu kata. Kesalahan dominan pada penghilangan fonem dan penambahan fonem yang berpengaruh pada kata tersebut dan dapat mengubah maknanya.

Secara keseluruhan dari penjelasan hasil penelitian di atas data dikumpulkan dari hasil membaca, mencari, setelah itu mencatat temuan. Pada Majalah Toga kesalahan yang dominan yaitu kesalahan pada tataran ejaan pengunaan huruf yang bercetak miring pada bahasa daerah atau bahasa asing. Pada majalah tersebut banyak ditemukan pengunaan bahasa asing tetapi tidak dicetak miring yang sesuai dengan kaidah kebahsasaan.

Tabel 1.1 Contoh Kesalahan Berbahasa dari Tataran Ejaan.

\begin{tabular}{|c|c|c|}
\hline Kesalahan Ejaan & Penulisan Salah & Penulisan Benar \\
\hline $\begin{array}{l}\text { Kesalahan Penulisan Huruf } \\
\text { Kapital }\end{array}$ & $\begin{array}{l}\text { (1)"Pucat masih tersorot } \\
\text { dari Wajah Barun" }\end{array}$ & $\begin{array}{l}\text { (1)"Pucat masih tersorot } \\
\text { dari wajah Barun" }\end{array}$ \\
\hline Kesalahan peulisan kata & $\begin{array}{l}\text { (2)"Inilah yang utama, } \\
\text { jangan pernah lupa untuk } \\
\text { selalu melibatkan Dis yang } \\
\text { maha kuasa" }\end{array}$ & $\begin{array}{l}\text { (2)"Inilah yang utama, } \\
\text { jangan pernah lupa untuk } \\
\text { selalu melibatkan Dia yang } \\
\text { mahakuasa" }\end{array}$ \\
\hline $\begin{array}{l}\text { Kesalahan penulisan kata } \\
\text { depan }\end{array}$ & $\begin{array}{l}\text { (3)"Semoga jurusan PGMI } \\
\text { juga dapat mengadakan } \\
\text { kompetisi sendiri baik } \\
\text { untuk mahasiswa PGMI } \\
\text { IAIN Surakarta ataupun } \\
\text { diluar IAIN Surkarta” }\end{array}$ & $\begin{array}{l}\text { (3)“Semoga jurusan PGMI } \\
\text { juga dapat mengadakan } \\
\text { kompetisi sendiri baik } \\
\text { untuk mahasiswa PGMI } \\
\text { IAIN Surakarta ataupun di } \\
\text { luar IAIN Surkarta" }\end{array}$ \\
\hline & $\begin{array}{l}\text { (4)"Mendirikan sebuah } \\
\text { fakultas ada beberapa } \\
\text { syarat yang harus dipenuhi } \\
\text { disalah satunya adalah } \\
\text { jumlah mahasiswa ideal" } \\
\text { (5)"Kegiatan-kegiatan } \\
\text { yang di lakukan didalam }\end{array}$ & $\begin{array}{l}\text { (4)"Mendirikan sebuah } \\
\text { fakultas ada beberapa } \\
\text { syarat yang harus dipenuhi } \\
\text { di salah satunya adalah } \\
\text { jumlah mahasiswa ideal" } \\
\text { (5)"Kegiatan-kegiatan } \\
\text { yang di lakukan didalam }\end{array}$ \\
\hline
\end{tabular}




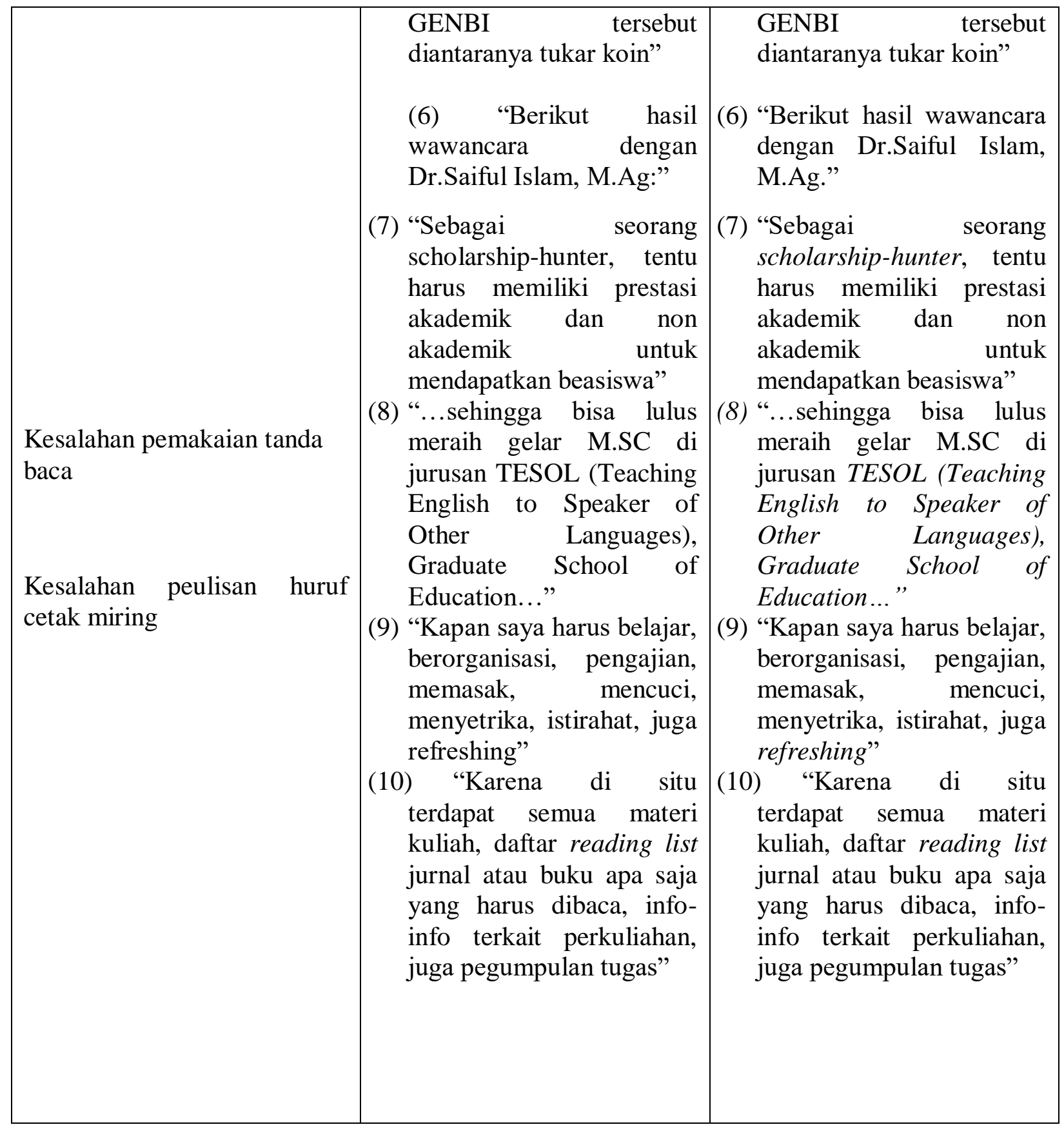

Tabel 1.2 Contoh Kesalahan Berbahasa dari Tataran Sintaksis.

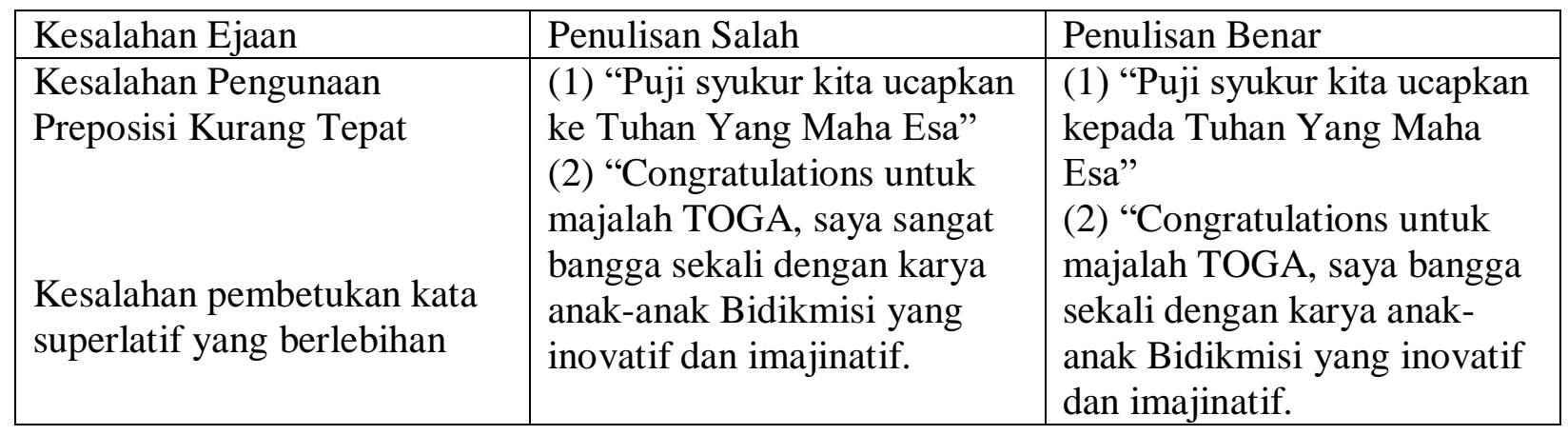




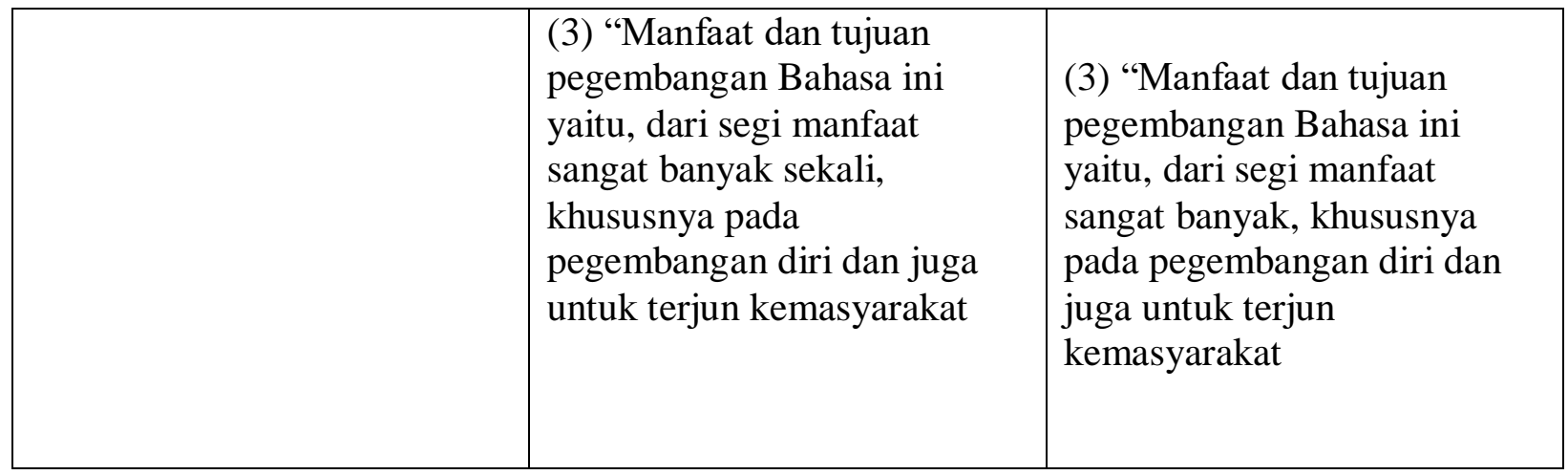

Tabel 1.3 Contoh Kesalahan Berbahasa dari Tataran Ejaan Semantik.

\begin{tabular}{|c|c|c|}
\hline Kesalahan Ejaan & Penulisan Salah & Penulisan Benar \\
\hline $\begin{array}{l}\text { Kesalahan Pengunaan } \\
\text { Kalimat Tidak Baku }\end{array}$ & $\begin{array}{l}\text { (1)"Mata menukik pada jarum } \\
\text { jam yang menunjukkan angka } \\
06.45 \text { WIB" } \\
\text { (2)"Daging korban itu akan di } \\
\text { bagikan kepada yang berhak } \\
\text { menerimanya" } \\
\text { (3)“Acara pelepasan para } \\
\text { wisudawan akan dimulai } \\
\text { pukul 08.00" }\end{array}$ & $\begin{array}{l}\text { (1)"Mata menukik pada jarum } \\
\text { jam yang menunjukkan pukul } \\
06.45 \text { WIB" } \\
\text { (2)"Daging kurban itu akan di } \\
\text { bagikan kepada yang berhak } \\
\text { menerimanya" } \\
\text { (3)“Acara penglepasan para } \\
\text { wisudawan akan dimulai } \\
\text { pukul 08.00" }\end{array}$ \\
\hline
\end{tabular}

Tabel 1.4 Contoh Kesalahan Berbahasa dari Tataran Ejaan Morfologi.

\begin{tabular}{|l|l|l|}
\hline Kesalahan Ejaan & Penulisan Salah & Penulisan Benar \\
\hline Kesalahan Afiksasi & (1)“Jika dihitung dalam & (1) "Jika dihitung dalam \\
ukura persen rektor & ukuran persen rektor \\
mengkalkulasi kelebihanya & mengalkulasi kelebihanya \\
$80 \%$ lebih banyak dari & $\begin{array}{l}80 \% \text { lebih banyak dari } \\
\text { kekuranganya" }\end{array}$ \\
& $\begin{array}{l}\text { kekuranganya" } \\
\text { (2) "Beruntungnya, mentor } \\
\text { bisa mengkondusifkan sesi } \\
\text { belajar dengan games." }\end{array}$ & $\begin{array}{l}\text { (2) "Beruntungnya, mentor } \\
\text { bisa mengondusifkan sesi } \\
\text { belajar dengan games." san }\end{array}$ \\
\hline
\end{tabular}


Tabel 1.5 Contoh Kesalahan Berbahasa dari Tataran Ejaan Fonologi.

\begin{tabular}{|c|c|c|}
\hline Kesalahan Ejaan & Penulisan Salah & Penulisan Benar \\
\hline $\begin{array}{l}\text { Kesalahan penghilangan /n/ } \\
\text { pada kata "stadar" }\end{array}$ & $\begin{array}{l}\text { (1)"Kita } \text { harus memeuhi } \\
\text { stadar 7 yang terdapat di } \\
\text { borang" }\end{array}$ & $\begin{array}{ll}\text { (1)'Kita } & \text { harus memeuhi } \\
\text { standar } 7 & \text { yang terdapat di } \\
\text { borang" } & \end{array}$ \\
\hline $\begin{array}{l}\text { Kesalahan penambahan /n/ } \\
\text { pada kata "sehari-harin" }\end{array}$ & $\begin{array}{l}\text { (2)"Menurut } \\
\text { kemampuan yang paling } \\
\text { penting dimiliki oleh } \\
\text { mahasiswa adalah menulis } \\
\text { karena menulis menjadi suatu } \\
\text { kewajiban kehidupan sehari- } \\
\text { harin dan kita perlu terus } \\
\text { mengembangakan } \\
\text { kemampuan tersebut", }\end{array}$ & $\begin{array}{l}\text { (2)"Menurut } \\
\text { kemampuan yang paling } \\
\text { penting dimiliki oleh } \\
\text { mahasiswa adalah menulis } \\
\text { karena menulis menjadi suatu } \\
\text { kewajiban kehidupan sehari- } \\
\text { harin dan kita perlu terus } \\
\text { mengembangakan } \\
\text { kemampuan tersebut" }\end{array}$ \\
\hline $\begin{array}{l}\text { Kesalahan penghilangan /n/ } \\
\text { dan /p/ pada kata "trasfortasi" }\end{array}$ & $\begin{array}{l}\text { (3)"Surakarta diuntunkan } \\
\text { dengan akses trasfortasi yang } \\
\text { mudah dijangkau, yakni } \\
\text { berdekatan denga bandara } \\
\text { Internatioal Adi Soemarmo } \\
\text { dan juga dengan jalur kereta } \\
\text { api”" }\end{array}$ & $\begin{array}{l}\text { (3)"Surakarta diuntunkan } \\
\text { dengan akses transportasi } \\
\text { yang mudah dijangkau, yakni } \\
\text { berdekatan denga bandara } \\
\text { Internatioal Adi Soemarmo } \\
\text { dan juga dengan jalur kereta } \\
\text { api" }\end{array}$ \\
\hline
\end{tabular}

\section{Hasil Pembahasan}

Dalam bab ini akan dipaparkan megenai hasil pembahasan analisis kesalahan berbahasa pada majalah Bidikmisi edisi III bulan Desember. Dari 48 halaman pada majalah ditemukan beberapa halaman yang terdapat kesalahan berbahasa. Kesalahan berbahasa tersebut berupa (a) kesalahan ejaan, (b) kesalahan morfologi, (c) kesalahan sintaksis, (d) kesalahan semantik, dan (e) kesalahan fonologi.

\section{Kesalahan Pada Tataran Ejaan}

III

Di bawah ini merupakan data yang menunjukkan kesalahan ejaan pada Majalah Toga Edisi

(1) "Pucat masih tersorot dari Wajah Barun"

Berdasarkan data di atas, dapat dianalisis bahwa terdapat kesalahan penulisan yaitu "Wajah Barun" seharusnya ditulis tidak menggunakan huruf kapital "wajah Barun", Kalimat di atas merupakan kesalahan pemakaian huruf karena pengunaan huruf kapital di tengah-tengah kalimat. Kalimat yang benar sebagai berikut.

(1a) "Pucat masih tersorot dari wajah Barun"

(2) "Inilah yang utama, jangan pernah lupa untuk selalu melibatkan Dia yang maha kuasa" Berdasarkan data di atas, dapat dianalisis bahwa terdapat kesalahan penulisan yaitu "yang maha kuasa" seharusnya ditulis digabung "yang mahakuasa", Kalimat di atas merupakan kesalahan penulisan kata seharusnya maha kuasa digabung tidak dipisah. Kalimat yang benar sebagai berikut.

(2a) "Inilah yang utama, jangan pernah lupa untuk selalu melibatkan Dia yang mahakuasa" 
(3) "Semoga jurusan PGMI juga dapat mengadakan kompetisi sendiri baik untuk mahasiswa PGMI IAIN Surakarta ataupun diluar IAIN Surkarta"

"Mendirikan sebuah fakultas ada beberapa syarat yang harus dipenuhi disalah satunya adalah jumlah mahasiswa ideal"

"Kegiatan-kegiatan yang di lakukan didalam GENBI tersebut diantaranya tukar koin”

Berdasarkan data di atas, dapat dianalisis bahwa terdapat kesalahan penulisan yaitu "diluar" dan "disalah" seharusnya ditulis menggunakan spasi pada kata depan "di luar"dan "di salah". Kalimat di atas merupakan kesalahan penulisan kata depan yang seharusnya pada diluar, disalah dan didalam menggunakan spasi. Kalimat yang benar sebagai berikut.

(3a) "Semoga jurusan PGMI juga dapat mengadakan kompetisi sendiri baik untuk mahasiswa PGMI IAIN Surakarta ataupun di luar IAIN Surkarta"

(3b) "Mendirikan sebuah fakultas ada beberapa syarat yang harus dipenuhi di salah satunya adalah jumlah mahasiswa ideal"

(3c) "Kegiatan-kegiatan yang dilakukan di dalam GENBI tersebut diantaranya tukar koin"

(4) "Berikut hasil wawancara dengan Dr.Saiful Islam, M.Ag:"

Berdasarkan data di atas, dapat dianalisis bahwa terdapat kesalahan penulisan yaitu "M.Ag:" seharusnya ditulis tidak menggunakan titik dua pada kata gelar seharunya "M.Ag". Kalimat di atas merupakan kesalahan pemakaian tanda baca karena seharusnya setelah gelar tedapat tanda titik (.) bukan titik dua. Kalimat yang benar sebagai berikut.

(4a) "Berikut hasil wawancara dengan Dr.Saiful Islam, M.Ag."

(5) "Sebagai seorang scholarship-hunter, tentu harus memiliki prestasi akademik dan non akademik untuk mendapatkan beasiswa"”

Berdasarkan data di atas, dapat dianalisis bahwa terdapat kesalahan penulisan yaitu "scholarshiphunter" seharusnya ditulis cetak miring "scholarship-hunter". Dalam PUEBI cetak miring dipakai untuk menuliskan kata atau ungkapan dalam bahasa daerah atau bahasa asing. Kalimat yang benar sebagai berikut.

(5a) "Sebagai seorang scholarship-hunter, tentu harus memiliki prestasi akademik dan non akademik untuk mendapatkan beasiswa"

(6) "Sehingga bisa lulus meraih gelar M.SC di jurusan TESOL (Teaching English to Speaker of Other Languages), Graduate School of Education"

Berdasarkan data di atas, dapat dianalisis bahwa terdapat kesalahan penulisan yaitu "TESOL (Teaching English to Speaker of Other Languages), Graduate School of Education ..." seharusnya ditulis cetak miring "TESOL (Teaching English to Speaker of Other Languages), Graduate School of Education”. DalamPUEBI huruf miring dipakai untuk menuliskan kata atau ungkapan dalam bahasa daerah atau bahasa asing. Kalimat yang benar sebagai berikut.

(6a) "Sehingga bisa lulus meraih gelar M.SC di jurusan TESOL (Teaching English to Speaker of Other Languages), Graduate School of Educatio ..." 
(7) "Kapan saya harus belajar, berorganisasi, pengajian, memasak, mencuci, menyetrika, istirahat, juga refreshing"

Berdasarkan data di atas, dapat dianalisis bahwa terdapat kesalahan penulisan yaitu "refreshing"seharusnya ditulis cetak miring "refreshing”. Dalam PUEBI cetak miring dipakai untuk menuliskan kata atau ungkapan dalam bahasa daerah atau bahasa asing. Atau lebih baik diubah dalam Bahasa Indonesia kata yang memiliki makna yang sama yaitu liburan. Kalimat yang benar sebagai berikut.

(7a) "Kapan saya harus belajar, berorganisasi, pengajian, memasak, mencuci, menyetrika, istirahat, juga refreshing"

(8) "Karena di situ terdapat semua materi kuliah, daftar reading list jurnal atau buku apa saja yang harus dibaca, info-info terkait perkuliahan, juga pegumpulan tugas"

Berdasarkan data di atas, dapat dianalisis bahwa terdapat kesalahan penulisan yaitu "reading lis" seharusnya ditulis cetak miring "reading list". Dalam PUEBI huruf miring dipakai untuk menuliskan kata atau ungkapan dalam bahasa daerah atau bahasa asing. Atau lebih baik diubah dalam Bahasa Indonesia kata yang memiliki makna sama yaitu daftar bacaan. Kalimat yang benar sebagai berikut.

(8a) "Karena di situ terdapat semua materi kuliah, daftar reading list jurnal atau buku apa saja yang harus dibaca, info-info terkait perkuliahan, juga pegumpulan tugas"

\section{Kesalahan Pada Tataran Sintaksis}

Dibawah ini merupakan data yang menunjukkan kesalahan ejaan pada majalah bidikmisi edisi III.

Kesalahan Berbahasa pada Frasa

(1) "Puji syukur kita ucapkan ke Tuhan Yang Maha Esa"

Berdasarkan data di atas, dapat dianalisis bahwa terdapat kesalahan penulisan yaitu "ke" seharusnya ditulis "kepada", Pada kalimat di atas, penggunaan preposisi ke kurang tepat. Pada konteks tersebut preposisi ke lebih baik dihilangkan karena hanya menyatakan tempat.

(1a) "Puji Syukur kita panjatkan kepada Tuhan Yang Maha Esa"

(2) "Congratulations untuk majalah TOGA, saya sangat bangga sekali dengan karya anakanak Bidikmisi yang inovatif dan imajinatif"

(3) "Manfaat dan tujuan pegembangan Bahasa ini yaitu, dari segi manfaat sangat banyak sekali, khususnya pada pegembangan diri dan juga untuk terjun kemasyarakat"

Berdasarkan data di atas, dapat dianalisis bahwa terdapat kesalahan penulisan yaitu "sangat bangga sekali" dan "sangat banyak sekali" seharusnya ditulis tidak berlebihan "bangga sekali" dan "sangat banyak", Kalimat di atas merupakan kesalahan pembetukan kata superlatif yang berlebihan. Kalimat yang benar sebagai berikut. 
(2a) "Congratulations untuk majalah TOGA, saya bangga sekali dengan karya anak-anak Bidikmisi yang inovatif dan imajinatif"

(3b) "Manfaat dan tujuan pegembangan Bahasa ini yaitu, dari segi manfaat sangat banyak, khususnya pada pegembangan diri dan juga untuk terjun kemasyarakat"

\section{Kesalahan Pada Tataran Semantik}

(1) "Mata menukik pada jarum jam yang menunjukkan angka 06.45 WIB"

Berdasarkan data di atas, dapat dianalisis bahwa terdapat kesalahan penulisan yaitu "angka" seharusnya ditulis "pukul", Kalimat di atas merupakan kesalahan pada kalimat yang tidak baku seharusnya angka diganti menjadi pukul. Kalimat yang benar sebagai berikut.

(1a) "Mata menukik pada jarum jam yang menunjukkan angka 06.45 WIB"

(2) "Daging korban itu akan di bagikan kepada yang berhak menerimanya"

Berdasarkan data di atas, dapat dianalisis bahwa terdapat kesalahan penulisan yaitu "korban" seharusnya ditulis tidak menggunakan huruf kapital "kurban", Kata kurban dan korban yang berasal dari bahasa arab yaitu qurban. Merupakan kata baku dalam bahasa Indonesia. Akibat tidak kehati hatian pemakai bahasa, kedua kata tersebut sering di pertukarkan pemakaiannya. Kalimat yang benar sebagai berikut.

(2a) "Daging kurban itu akan dibagikan kepada yang berhak menerimanya"

\section{Kesalahan Pada Tataran Morfologi}

Setiap kata yang pembentukan katanya tidak sesuai dengan kaidah pembentukan kata menurut kaidah yang berlaku di era saat ini maka termasuk dalam kesalahan kaidah. Bentuk-bentuk kesalahan pada tataran morfologi meliputi kesalahan afiksasi, kesalahan reduplikasi, dan kesalahan pemajemukan.

(1) "Jika dihitung dalam ukuran persen rektor mengkalkulasi kelebihanya $80 \%$ lebih banyak dari kekuranganya"

Berdasarkan data di atas, dapat dianalisis bahwa terdapat kesalahan afiksasi yaitu kata "mengkalkulasi" seharusnya menggunakan kata "mengalkulasi”. Dalam PUEBI kata dasar yang yang huruf awalnya K, T, S, dan P ketika mengalami proses afiksai, maka huruf awal tersebut lebur. Kalimat yang benar sebagai berikut.

(1a) "Jika dihitung dalam ukuran persen rektor mengalkulasi kelebihanya $80 \%$ lebih banyak dari kekuranganya"

(2) "Beruntungnya, mentor bisa mengkondusifkan sesi belajar dengan games"

Berdasarkan data di atas, dapat dianalisis bahwa terdapat kesalahan afiksasi yaitu kata "mengkondusifkan" seharusnya menggunakan kata "mengondusifkan". Dalam PUEBI kata dasar 
yang yang huruf awalnya $\mathrm{K}, \mathrm{T}, \mathrm{S}$, dan $\mathrm{P}$ ketika mengalami proses afiksai, maka huruf awal tersebut lebur. Kalimat yang benar sebagai berikut.

(2a) "Beruntungnya, mentor bisa mengondusifkan sesi belajar dengan games"

\section{Kesalahan Pada Tataran Fonologi}

(1) "Menurut Okta, kemampuan yang paling penting dimiliki oleh mahasiswa adalah menulis karena menulis menjadi suatu kewajiban kehidupan sehari-harin dan kita perlu terus mengembangakan kemampuan tersebut"

Berdasarkan data diatas, dapat dianalisis bahwa kesalahan penambahan /n/ pada kata "sehari-harin" seharusnya menggunakan kata "sehari-hari". Dalam KBBI "sehari-hari" memiliki makna atau arti yang serupa yaitu tiap-tiap hari. Kalimat yang benar sebagai berikut

(1a) "Menurut Okta, kemampuan yang paling penting dimiliki oleh mahasiswa adalah menulis karena menulis menjadi suatu kewajiban kehidupan sehari-hari dan kita perlu terus mengembangakan kemampuan tersebut."

(3) "Surakarta diuntunkan dengan akses trasfortasi yang mudah dijangkau, yakni berdekatan denga bandara Internatioal Adi Soemarmo dan juga dengan jalur kereta api"

Berdasarkan data di atas, dapat dianalisis bahwa kesalahan penghilangan /n/ dan /p/ pada kata "trasfortasi" seharusnya menggunakan kata "transportasi". Dalam KBBI "transportasi" memiliki makna atau arti yang serupa yaitu pengakutan barang oleh berbagai jenis kendaraan sesuai dengan kemajuan teknologi. Kalimat yang benar sebagai berikut

(2a) "Surakarta diuntunkan dengan akses transportasi yang mudah dijangkau, yakni berdekatan denga bandara Internatioal Adi Soemarmo dan juga dengan jalur kereta api”

(4) "Kita harus memeuhi stadar 7 yang terdapat di borang"

Berdasarkan data diatas, dapat dianalisis bahwa kesalahan penghilangan /n/ pada kata "stadar" seharusnya menggunakan kata "standar". Dalam KBBI standar memiliki makna atau arti yang serupa yaitu ukuran tertentu yang dipakai sebagai patokan. Kalimat yang benar sebagai berikut

(3a) "Kita harus memenuhi standar 7 yang terdapat di borang"

\section{SIMPULAN}

Berdasarkan hasil penelitian dan pembahasan yang telah dideskripsikan, dapat disimpulkan bahwa kesalahanan berbahasa merupakan kesalahan yang terjadi pada ujaran atau tulisan. Kesalahan tersebut merupakan bagian perubahan bahasa dari masa ke masa. Kesalahan berbahasa ini bisa terjadi pada siapa saja. Kesalaha berbahasa juga sering ditemuai dalam kegiatan belajar megajar. Kesalahan berbahasa sebaikya dapat dikuragi atau dihilangkan. Kesalahan berbahasa tersebut sering muncul dan banyak terjadi pada penulisan ilmiah. Beberapa kesalahan berbahasa dalam Majalah Toga Edisi III sebagai berikut. (1) Kesalahan ejaan terdiri atas (a) kesalahan pemakaian huruf (huruf kapital), (b) kesalahan pemakaian tanda baca) (2) Kesalahan morfologi terdiri atas kesalahan afiksasi dan kesalahan kata ulang. (4) Kesalahan sintaksis (5) Kesalahan Semantik (6) Selain empat kesalahan di 
atas terdapat pula kesalahan fonologi. Berdasarkan data diatas dapat disimpulkan bahwa kecenderungan kesalahan berbahasa pada tataran ejaan penulisan kata bercetak miring pada bahasa daerah dan bahasa asing. Pada majalah tersebut banyak ditemukan pengunaan bahasa asing tetapi tidak dicetak miring yang sesuai dengan kaidah kebahasaan. Kesalahan berbahasa pada penelitian ini dominan terhadap kesalahan berbahasa pada tataran ejaan penulisan kata bercetak miring pada bahasa daerah maupun bahasa asing.

\section{DAFTAR PUSTAKA}

Chaer, Abdul. 2012. Linguistik Umum. Jakarta: PT Rineka Cipta

Inderasari, Elen dan Tiya Agustina. 2017. Pembelajaran Bahasa Indonesia Pada Mahasiswa Asing dalam Program BIPA IAIN Surakarta. Jurnal Pendidikan Bahasa dan Sastra Indonesia volume 6, nomor 2.

Johan, Gio Mohamad Dan Yusrawati Jr Simatupang. 2017. Analisis Kesalahan Berbahasa Indonesia Secara Sintaktis Dalam Proses Diskusi Siswa Kelas IV Sdn Miri. Jurnal Visipena volume 8 Nomor 2

Nurwicaksono, Bayu Dwi dan Amelia, Diah.2018. Analisis Kesalahan Berbahasa Indonesia pada Teks Ilmiah Mahasiwa. Vol. 2 No. 2. AKSIS.

Setyawati, Nanik. 2010. Analisis Kesalahan Berbahasa Indonesia Surakarta: Yuma Pustaka.

Slamet. 2014. Problematika Bahasa Indonesia dan Pembelajarannya. Yogyakarta: Graha Ilmu

Suhardi. 2013. Pengantar Linguistik Umum. Yogyakarta: Ar-ruzz Media.

Supriani, Reni Dan Ida Rahmadani Siregar. 2016. Analisis Kesalahan Berbahasa. Jurnal Edukasi Kultura volume 1 momor 2

Verhaar dkk. 2001. Asas-Asas Linguitik Umum. Yogyakarta: Gadjah Mada University Press.

Wijana, Dewa Putu. 2011. Berkenaan dengan Linguistik. Yogyakarta: A.Com Advertising 